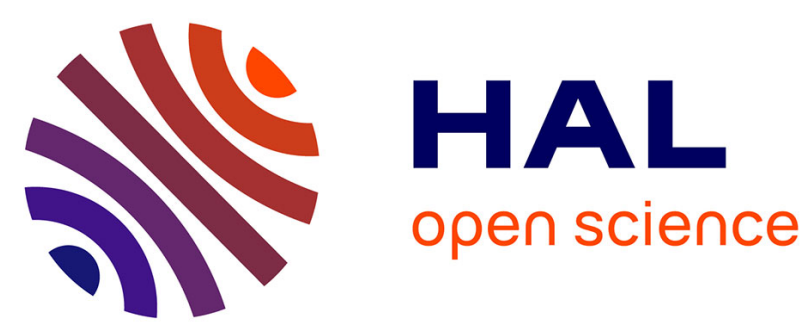

\title{
Mercury in Bay Bolete (Xerocomus badius): bioconcentration by fungus and assessment of element intake by humans eating fruiting bodies
}

Jerzy Falandysz, Anna Katarzyna Kojta, Grażyna Jarzyńska, Malgorzata

Drewnowska, Anna Dryżalowska, Daria Wydmańska, Izabela Kowalewska, Anna Wacko, Monika Szlosowska, Kannan Kurunthachalam, et al.

\section{To cite this version:}

Jerzy Falandysz, Anna Katarzyna Kojta, Grażyna Jarzyńska, Malgorzata Drewnowska, Anna Dryżalowska, et al.. Mercury in Bay Bolete (Xerocomus badius): bioconcentration by fungus and assessment of element intake by humans eating fruiting bodies. Food Additives and Contaminants, 2012, pp.1. 10.1080/19440049.2012.662702 . hal-00801034

\section{HAL Id: hal-00801034 \\ https://hal.science/hal-00801034}

Submitted on 15 Mar 2013

HAL is a multi-disciplinary open access archive for the deposit and dissemination of scientific research documents, whether they are published or not. The documents may come from teaching and research institutions in France or abroad, or from public or private research centers.
L'archive ouverte pluridisciplinaire HAL, est destinée au dépôt et à la diffusion de documents scientifiques de niveau recherche, publiés ou non, émanant des établissements d'enseignement et de recherche français ou étrangers, des laboratoires publics ou privés. 


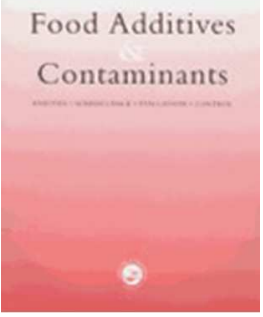

\section{Mercury in Bay Bolete (Xerocomus badius): bioconcentration by fungus and assessment of element intake by humans eating fruiting bodies}

\begin{tabular}{|c|c|}
\hline Journal: & Food Additives and Contaminants \\
\hline Manuscript ID: & TFAC-2011-508.R1 \\
\hline Manuscript Type: & Original Research Paper \\
\hline Date Submitted by the Author: & 22-Jan-2012 \\
\hline Complete List of Authors: & $\begin{array}{l}\text { Falandysz, Jerzy; University of Gdańsk, Institute of Environmental Sciences } \\
\text { \& Public Health } \\
\text { Kojta, Anna; University of Gdańsk, Chemistry; University of Gdańsk, } \\
\text { Institute of Environmental Sciences \& Public Health } \\
\text { Jarzyńska, Grażyna; University of Gdańsk, Institute of Environmental } \\
\text { Sciences \& Public Health } \\
\text { Drewnowska, Małgorzata; University of Gdańsk, Institute of Environmental } \\
\text { Sciences \& Public Health } \\
\text { Dryżałowska, Anna; University of Gdańsk, Institute of Environmental } \\
\text { Sciences \& Public Health } \\
\text { Wydmańska, Daria; University of Gdańsk, Institute of Environmental } \\
\text { Sciences \& Public Health } \\
\text { Kowalewska, Izabela; University of Gdańsk, Institute of Environmental } \\
\text { Sciences \& Public Health } \\
\text { Wacko, Anna; University of Gdańsk, Institute of Environmental Sciences \& } \\
\text { Public Health } \\
\text { Szlosowska, Monika; University of Gdańsk, Institute of Environmental } \\
\text { Sciences \& Public Health } \\
\text { Kurunthachalam, Kannan; Wadsworth Center, NYS Department of Health } \\
\text { Szefer, Piotr; Medical University of Gdańsk, Department of Food Sciences }\end{array}$ \\
\hline Methods/Techniques: & $\begin{array}{l}\text { Metals analysis - AAS, Reference materials, Statistical analysis, Risk } \\
\text { assessment }\end{array}$ \\
\hline Additives/Contaminants: & Heavy metals - mercury \\
\hline Food Types: & Mushrooms \\
\hline Abstract: & $\begin{array}{l}\text { Concentrations of } \mathrm{Hg} \text { were determined in } 221 \text { specimens of Bay Bolete and } \\
\text { in } 221 \text { samples of corresponding forest topsoil layer }(0-10 \mathrm{~cm}) \text { collected } \\
\text { from } 18 \text { sites across geographically and industrially diverse regions of }\end{array}$ \\
\hline
\end{tabular}


Poland in 2000-2008. Mercury concentrations in caps and stipes of Bay Bolete were strongly correlated $(p<0.0001)$, whereas the relationship between the $\mathrm{Hg}$ concentrations in soil and mushrooms varied depending on the sampling location. The Bay Bolete showed a lower bioconcentration potential of $\mathrm{Hg}$ at sites with elevated soil $\mathrm{Hg}$ concentrations and a higher at sites with lower $\mathrm{Hg}$ concentrations in soil. In a view of $\mathrm{Hg}$ content, the consumption of Bay Boletes (caps or a whole mushrooms) at the regions surveyed at least at a rate up to $2.5 \mathrm{~kg}$ per capita weekly in a mushrooming season is safe and will not result in exceeding of currently allowable $\mathrm{Hg}$ intake doses.

\section{SCHOLARONE ${ }^{m}$ \\ Manuscripts}




\section{Mercury in Bay Bolete (Xerocomus badius): bioconcentration by fungus}

\section{2 and assessment of element intake by humans eating fruiting bodies}

3

4

5 J. Falandysz ${ }^{\mathrm{a}}$, A.K. Kojta ${ }^{\mathrm{a}^{*},}$, G. Jarzyńska ${ }^{\mathrm{a}}$, M. Drewnowska ${ }^{\mathrm{a}}$, A. Dryżałowska ${ }^{\mathrm{a}}$, D. Wydmańska ${ }^{\mathrm{a}}$,

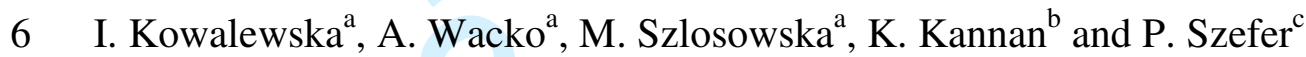

$9{ }^{a}$ Research Group of Environmental Chemistry, Ecotoxicology \& Food Toxicology, Institute of

10 Environmental Sciences \& Public Health, University of Gdańsk,

1118 Sobieskiego Str., PL 80-952 Gdańsk, Poland

12

$13{ }^{b}$ Wadsworth Center, New York State Department of Health, and Department of Environmental

14 Health Sciences, School of Public Health, State University of New York at Albany,

15 Empire State Plaza, Albany, NY 12201-0509, USA

16

$17{ }^{c}$ Department of Food Sciences, Medical University of Gdańsk, 107 Hallera Ave., PL 80-416

18 Gdańsk, Poland

\footnotetext{
* Corresponding author. Email:annakojta@gmail.com
} 


\section{Abstract}

20 Concentrations of mercury $(\mathrm{Hg})$ were determined in 221 specimens of Bay Bolete and in 221

21 samples of corresponding forest topsoil layer $(0-10 \mathrm{~cm})$ collected from 18 sites across 22 geographically and industrially diverse regions of Poland in 2000-2008. Mercury concentrations in 23 caps and stipes of Bay Bolete were strongly correlated $(\mathrm{p}<0.0001)$, whereas the relationship 24 between the $\mathrm{Hg}$ concentrations in soil and mushrooms varied depending on the sampling location. 25 The Bay Bolete showed a lower bioconcentration potential of $\mathrm{Hg}$ at sites with elevated soil $\mathrm{Hg}$ 26 concentrations and a higher at sites with lower $\mathrm{Hg}$ concentrations in soil. In a view of $\mathrm{Hg}$ content,

27 the consumption of Bay Boletes (caps or a whole mushrooms) at the regions surveyed at least at a 28 rate up to $2.5 \mathrm{~kg}$ per capita weekly in a mushrooming season is safe and will not result in 29 exceeding of currently allowable $\mathrm{Hg}$ intake doses.

31 Keywords: food contamination; heavy metals; mushrooms; nutrition; mercury.

\section{Introduction}

34 Contamination of food resources with $\mathrm{Hg}$ from environmental releases of this hazardous metal is 35 a continuous threat to food safety (Olivero et al., 2002). In order to protect human exposure from $36 \mathrm{Hg}$ found in the food supply, the Joint FAO/WHO Expert Committee on Food Additives 37 established for total $\mathrm{Hg}$ a new provisional tolerable weekly intake (PTWI) of $0.004 \mathrm{mg} \mathrm{kg}^{-1}$ body 38 weight in 2010 (JECFA, 2010). A few earlier studies have shown that wild mushrooms can 39 accumulate mercury from the soil to a considerable amount (Alonso et al., 2000; Chudzyński et 40 al., 2009 and 2011; Falandysz et al., 2001a, 2002a-b, 2003a-d and 2004; Melgar et al., 2009;

41 Stijve and Cardinale, 1974; Zimmermannova et al., 2001). The Bay Bolete mushroom, due to its 42 size and seasonal abundance, is by volume, one of the dominant species of mushrooms harvested 
43 in wild each year in Poland. For example, 1705 tons of mushrooms have been harvested from the 44 wild by commercial harvesters in Poland in 2000, and it was 5914 tons in 2008, of which 3275 45 tons were solely of the genera Xerocomus (X. badius, X. subtomentosus, X. chrysenteron) (GUS, 46 2009). These quantities do not account for the amount harvested annually by numerous non47 commercial collectors in Poland, where wild mushroom picking is a traditional activity.

48 Some species of higher fungi (macromycetes) are known for their ability to accumulate 49 metallic elements including hazardous heavy metals such as $\mathrm{Hg}, \mathrm{Cd}$ or $\mathrm{Pb}$ (Brzostowski et al., 502009 and 2011a-b; Chudzyński and Falandysz, 2008; Doğan et al., 2006; Falandysz et al., 2001b, 51 2007a-c, 2008a-b and 2011; Frankowska et al., 2010; Gast et al., 1988; Gucia et al., 2011a-b; 52 Jarzyńska et al., 2011; Kojta et al., 2011; Malinowska et al., 2004; Melgar et al., 1998; Stijve and 53 Besson, 1976). Concentrations of trace elements in underlying soil or other substratum and 54 bioavailability are among the factors that can affect the concentrations of metals in fruiting 55 bodies (carpophores) of fungi (Bargagli and Baldi, 1984; Borovička et al., 2010; Falandysz et al., 56 1994; Řanda and Kučera, 2004; Stijve et al., 2004).

Nevertheless, in nature, it is difficult to establish quantitative relationship between the

58 concentrations of metallic element and metalloid content in mushrooms and the underlying 59 substratum (Gast et al., 1988; Falandysz et al., 2011). If mushrooms and topsoil were collected 60 concurrently from both contaminated and background (free of local pollution sources) areas, it is 61 possible to elucidate the relationship soil metal concentrations and residue levels in mushrooms 62 (Barcan et al., 1998; Falandysz et al., 2002c; Carvalho et al., 2005; Stijve and Roschnik, 1974).

63 In background areas, Cd concentrations in fruiting bodies of the King Bolete (Boletus edulis) 64 fungus increased with $\mathrm{Cd}$ concentrations in topsoil (Falandysz et al., 2011). A positive 65 association was found between soil methyl mercury concentrations and the concentrations in 66 fruiting bodies of fungi, although the number of evidences is very limited (Fischer et al., 1995). A 
67 similar relationship was also observed for total $\mathrm{Hg}$ in Parasol Mushroom (Macrolepiota procera) 68 (Falandysz and Chwir, 1997).

69 In this study, we determined total $\mathrm{Hg}$ concentrations in Bay Bolete (X. badius), and in 70 forest topsoil layer below the fruit bodies, at eighteen sites distantly distributed across Poland. 71 We examined bioconcentration potential of $\mathrm{Hg}$ in Bay Bolete and daily intake rates of $\mathrm{Hg}$ from 72 mushroom consumption. Bay Bolete is a mycorrhizal fungus associated with coniferous 73 woodland and mixed woodland. The symbiotic trees are supplied by fungus with portion of 74 minerals absorbed by mycelium. Nevertheless, plants are very poor in $\mathrm{Hg}$ while mushrooms are 75 relatively abundant in $\mathrm{Hg}$ (Cibulka et al., 1996).

\section{$76 \quad$ Materials and methods}

77 Bay Bolete, Xerocomus badius (Fr.) Kühn, is a mycorrhizal mushroom and is a common 78 species found in mixed woodlands of several European countries. The mushroom and topsoil 79 samples $(0-10 \mathrm{~cm}$ layer; ca. $100 \mathrm{~g})$ were collected from eighteen, geographically diverse 80 regions of Poland during 2000-2008 (Figure 1; Table 1). Mushrooms were cleaned up from 81 adhering plant material and soil particles with a plastic knife and brush and, if necessary, the 82 bottom part of stipe was cut away. Next, the fruiting bodies were initially air-dried for $48 \mathrm{~h}$, and 83 then were oven-dried at $65^{\circ} \mathrm{C}$ to a constant weight. Dried mushrooms were crushed and ground 84 in a ceramic mortar to fine powder and kept in a sealed polyethylene bags. Soil substrate 85 samples, after the removal of visible organisms, stones, sticks, and leaves, were air-dried for 86 approximately 10 weeks and then sieved through a $2 \mathrm{~mm}$ sieve (Falandysz, 2002; Falandysz et 87 al., 2003a).

88 Analysis of total $\mathrm{Hg}$ content in fruiting bodies and soil was conducted using a direct 89 sample thermal decomposition coupled with gold wool trap, desorption and cold-vapor atomic 
90 absorption spectroscopy (CV-AAS; Mercury analyzer type MA-2000, Nippon Instruments

91 Corporation, Takatsuki, Japan) determination (Jarzyńska and Falandysz, 2011a). The procedure

92 for $\mathrm{Hg}$ determination was validated through analysis of several certified reference materials

93 including: CS-M-1 (dried fruiting bodies of mushroom, Cow Bolete Suillus bovinus); CTA-OTL-1

94 (tobacco leaves) and INCT-TL-1 (tea leaves) produced by the Institute of Nuclear Chemistry and

95 Technology in Warsaw, Poland. The declared total Hg contents of the certified reference materials

96 were: $0.174 \pm 0.018 \mu \mathrm{g} \mathrm{g}^{-1} \mathrm{dw}$ for CS-M-1 (our measurements were $0.179 \pm 0.008 \mu \mathrm{g} \mathrm{g}^{-1} \mathrm{dw} ; n=3$ );

$970.043 \mu \mathrm{g} \mathrm{g}^{-1} \mathrm{dw}$ for CTA-OTL-1 (our measurements were $0.046 \pm 0.002 \mu \mathrm{g} \mathrm{g}^{-1} \mathrm{dw} ; n=3$ ); and

$980.005 \pm 0.001 \mu \mathrm{g} \mathrm{g}^{-1} \mathrm{dw}$ for INCT-TL-1 (our measurements were $0.005 \pm 0.000 \mu \mathrm{g} \mathrm{g}^{-1} \mathrm{dw} ; n=3$ ). In

99 addition, with every set of 10 mushroom or soil samples analyzed, one procedural blank was

100 included; no contamination or interference was found in blanks (Jarzyńska and Falandysz, 2011a).

101 Data were evaluated statistically using the computer software Statistica version 8.0.

102 Mercury concentrations in mushrooms and soils have no Gaussian distribution. Data

103 transformation, which aimed to obtain their log-normal distribution, was unsuccessful. Moreover,

104 data variances were heterogeneous (Barlett test). Consequently, statistical analyses were

105 performed with nonparametric tests. A nonparametric Tukey-type multiple comparisons

106 (Nemenyi test) following nonparametric analysis of variance (Kruskall-Wallis test) were applied

107 to indicate diversity of $\mathrm{Hg}$ content in soil substratum, and caps and stipes or whole fruiting bodies

108 of specimens from the certain sampling sites surveyed. Further examination of differences in $\mathrm{Hg}$

109 concentrations between the caps (also stipes and soil) from certain localizations was made using

110 Mann-Whitney $U$ test.

111

\section{Results and discussion}

$113 \quad$ Hg in fruiting bodies 
114 Concentrations of total $\mathrm{Hg}$ in caps and stipes of Bay Bolete were high in specimens collected

115 from Złotoryja (site $12 \mathrm{Z}$ ), and these concentrations differed significantly from samples collected

116 at other locations (Figure 3). The arithmetic mean concentrations of $\mathrm{Hg}$ in Bay Bolete's cap

117 varied between $0.051 \pm 0.030$ and $1.0 \pm 1.1 \mu \mathrm{g} \mathrm{g}^{-1} \mathrm{dw}$, depending on the location. The 118 corresponding concentrations of $\mathrm{Hg}$ in stipes of Bay Bolete at these sites were between $1190.027 \pm 0.018$ and $0.68 \pm 0.86 \mu \mathrm{g} \mathrm{Hg} \mathrm{g}^{-1} \mathrm{dw}$. The whole fruiting bodies collected from Kłodzka 120 Dale (14 KD) contained $0.26 \pm 0.06 \mu \mathrm{g} \mathrm{Hg} \mathrm{g}^{-1} \mathrm{dw}$. A total Hg concentration of $1.0 \mu \mathrm{g} \mathrm{g}^{-1} \mathrm{dw}(0.1$ $121 \mu \mathrm{g} \mathrm{g}^{-1}$ wet weight) exceeded in two specimens from Włoszczowa (15 W) and two from Złotoryja 122 (12 Z) (Table 1).

123 Mercury concentrations in Bay Bolete at sites that are considered as background 124 (unpolluted) areas varied between $0.051 \pm 0.030$ and $0.32 \pm 0.17 \mu \mathrm{g} \mathrm{g}^{-1} \mathrm{dw}$ in caps and between $1250.027 \pm 0.018$ and $0.23 \pm 0.12 \mu \mathrm{g} \mathrm{g}^{-1} \mathrm{dw}$ in stipes (Table 1 ). These concentrations are relatively 126 small and comparable to a range of values between $0.26 \pm 0.17$ and $0.50 \pm 0.10 \mu \mathrm{g} \mathrm{g}^{-1} \mathrm{dw}$ in caps, 127 and between $0.089 \pm 0.026$ and $0.16 \pm 0.07 \mu \mathrm{g} \mathrm{g}^{-1} \mathrm{dw}$ in stipes, reported for the mushroom Larch 128 Bolete (Suillus grevillei) as well as between $0.095 \pm 0.082$ and $0.28 \pm 0.07 \mu \mathrm{g} \mathrm{g}^{-1} \mathrm{dw}$ in caps and 129 between $0.045 \pm 0.018$ and $0.13 \pm 0.02 \mu \mathrm{g} \mathrm{g}^{-1} \mathrm{dw}$ in stipes reported for Slippery Jack (Suillus 130 luteus) in Poland (Chudzyński et al., 2009 and 2011). The fungus, Bay Bolete, can be considered 131 as a weak accumulator of $\mathrm{Hg}$ in fruiting bodies in comparison with King Bolete (Boletus edulis) 132 which contained between 1.2 \pm 1.4 and 7.6 $\pm 3.1 \mu \mathrm{g} \mathrm{Hg} \mathrm{g}^{-1} \mathrm{dw}$ in caps or with Parasol Mushroom 133 (Macrolepiota procera) which contained between $1.1 \pm 1.0$ and $8.4 \pm 7.4 \mu \mathrm{g} \mathrm{Hg} \mathrm{g}^{-1} \mathrm{dw}$ in caps 134 (Falandysz and Gucia, 2008; Falandysz et al., 2007b and 2008a).

135 The caps of Bay Bolete, on average, contained higher concentrations of $\mathrm{Hg}$ than the stipes 136 (Table 1). The median value for caps to stipe $\mathrm{Hg}$ concentration quotient $\left(\mathrm{Q}_{\mathrm{C} / \mathrm{S}}\right)$, calculated for 221 137 specimens collected across Poland, was 1.7, and the arithmetic mean was 1.8 $\pm 0.8(0.1-6.6)$. 
138 Nevertheless, the total $\mathrm{Hg}$ content in caps of Bay Bolete was significantly correlated with the

139 content in stipes $(r=0.95 ; \mathrm{p}<0.0001$; Figure 2$)$.

$140 \quad$ Hg content in topsoil and its relation to concentrations in mushroom

141 Soil $\mathrm{Hg}$ content is an important factor that affects the concentrations of this element in terrestrial 142 plants and edible mushrooms. A concentration of $\mathrm{Hg}$ of $1.0 \mu \mathrm{g} \mathrm{g}^{-1} \mathrm{dw}$ has been suggested as a 143 reference value for agricultural soil (Rundgren et al., 1992). No such value has been reported for 144 forest soils in Poland. The median $\mathrm{Hg}$ concentrations in topsoil at most sampling sites in this 145 study were below $0.1 \mu \mathrm{g} \mathrm{g}^{-1}$ (Table 1). In our earlier surveys, we found that the median values of 146 total $\mathrm{Hg}$ concentrations in forest soils in central and northern Europe were below $0.1 \mu \mathrm{g} \mathrm{g}^{-1}$ 147 (Chudzyński et al., 2009 and 2011; Falandysz and Bielawski, 2001 and 2007; Falandysz and 148 Brzostowski, 2007; Falandysz and Chwir, 1997; Falandysz et al., 2001a, 2002a-c, 2003a-d and 149 2004). It is known that the forest upper layer of soil that is rich in organic matter can easily 150 absorb $\mathrm{Hg}$ deposited from the atmosphere and from weathering of parent bedrocks (Suchara and 151 Sucharová, 2002). Nevertheless, the content of organic matter in the top 0-10 cm forest soil layer 152 vary greatly depending on the region, bedrock, vegetation, and age of the forest. The Critical 153 Limit (CL) proposed for $\mathrm{Hg}(\mathrm{II})$ in soil is $0.13 \mu \mathrm{g} \mathrm{g}^{-1}$ (when soil properties are taken into account, 154 the value ranges between 0.04 and $1.2 \mu \mathrm{g} \mathrm{g}^{-1}$ ). The soil organic matter (SOM) normalized CL is $1553.3 \mu \mathrm{g} \mathrm{Hg} \mathrm{g}^{-1}$ of SOM (varies between 0.03 and $3.3 \mu \mathrm{g} \mathrm{g}^{-1}$ ). This $\mathrm{CL}$ value is greater than the 156 value of $0.5 \mu \mathrm{g} \mathrm{g}^{-1} \mathrm{SOM}$, used to estimate $\mathrm{Hg}$ effects in European soil ecosystems (Tipping et al., 157 2010). The total $\mathrm{Hg}$ content in forest topsoil (0-10 $\mathrm{cm}$ layer) in this study, and in our earlier 158 studies across Poland, was well below the recently proposed CL value for $\mathrm{Hg}(\mathrm{II})$ of $0.13 \mu \mathrm{g} \mathrm{g}^{-1}$. 159 In earlier two studies, the concentrations of $\mathrm{Hg}$ in forest soils were found not dependent 160 on soil type and texture or were elevated in soils of loose sands and slightly clayey relatively rich 
161 in humus type (Falandysz et al., 2002b and 2003a). It is worth to mention that no relation with $\mathrm{Hg}$

162 of fruiting bodies and organic matter content or $\mathrm{pH}$ of the soils could be observed for fungi in a 163 several studies (Falandysz and Bielawski, 2007; Falandysz and Brzostowski, 2007). No such 164 relation could be observed also between soils organic matter content or $\mathrm{pH}$ and metals such as $\mathrm{Cd}$ 165 and $\mathrm{Pb}$ sequestered in fruiting bodies of several fungi (Gast et al., 1998), as well as of Ag, Al, Ba, $166 \mathrm{Ca}, \mathrm{Cd}, \mathrm{Co}, \mathrm{Cr}, \mathrm{Cu}, \mathrm{Fe}, \mathrm{Hg}, \mathrm{K}, \mathrm{Mg}, \mathrm{Mn}, \mathrm{Na}, \mathrm{Ni}, \mathrm{Sr}, \mathrm{Pb}, \mathrm{Rb}$ and $\mathrm{Zn}$ by Pioson Pax, Paxillus 167 involutus, mushroom (Brzostowski et al., 2011a), while uptake and sequestration in fruiting 168 bodies of metallic elements essential to fungi $(\mathrm{K}, \mathrm{Na}, \mathrm{Ca}, \mathrm{Mg}, \mathrm{Zn}, \mathrm{Cu})$ is largely regulated by 169 species. In other words, either organic matter content or $\mathrm{pH}$ of soils was found as not important 170 factors that can determine the trace metals bioavailability to fungi. Nevertheless, in the complex 171 process of minerals gaining and absorption by mycelium, and in case of mycorrhizal fungi theirs 172 further transfer to symbiotic plant (tree) and also transfer and sequestering in fruiting bodies there 173 are an unknown underlying variables.

174 The soils $\mathrm{Hg}$ concentrations increase moving from the north to the south of Poland 175 (Figure 3). This spatial trend can be related to the degree of industrialization and urbanization of 176 the areas surveyed. Dolnośląskie Voivodeship (the sites nos. 11-14; Fig, 1) is a highly 177 industrialized and urbanized region in Southern Poland and differences in soils bedrock 178 composition between the regions. Furthermore, industrial activities are predominant in 179 Świętokrzyskie Voivodeship (the sites nos. 15 and 16; Southern Poland), where soil $\mathrm{Hg}$ 180 concentrations varied considerably (Figs. 1 and 3, Table 1). Of the 18 locations surveyed in this 181 study, 17 locations exhibited no clear relationship between $\mathrm{Hg}$ concentration in Bay Bolete and 182 corresponding soil $\mathrm{Hg}$ content. At Karpacz $(13 \mathrm{~K})$, a tendency of increasing content of $\mathrm{Hg}$ in 183 caps/stipes with increasing soil $\mathrm{Hg}$ content was found. 
184 A potential of minerals uptake by fungus from the soil and further sequestration in

185 fruiting bodies is assessed using the common concept of bioconcentration factor (BCF) or 186 otherwise transfer factor or enrichment factor. They are simply the mushroom's constituent 187 concentration divided by the soil (or other substratum media) mineral constituent concentration. 188 The value of BCF for a given trace element is a measure of its site-specific bioavailability for 189 fungus.

190 Elevated concentration of $\mathrm{Hg}$ in topsoil and in parallel a good bioavailability are the 191 reasons for great concentrations of $\mathrm{Hg}$ in fruiting bodies of Bay Bolete at the Złotoryja site (Table

1921 ; site $12 \mathrm{Z}$ ). However, for the two highly contaminated specimens from the Włoszczowa site (15 $193 \mathrm{~W}$; containing 2.7 and $1.4 \mu \mathrm{g} \mathrm{Hg} \mathrm{g}^{-1} \mathrm{dw}$ in caps and 0.89 and $0.87 \mu \mathrm{g} \mathrm{Hg} \mathrm{g}^{-1} \mathrm{dw}$ in stipes), the 194 driving force for elevated concentrations seems to be great $\mathrm{Hg}$ bioavailability (BCF was 80 and 19516 for caps and 26 and 10 for stipes).

$196 \mathrm{Hg}$ content of topsoil from the Karpacz site was elevated (compared to the other locations 197 surveyed), although $\mathrm{Hg}$ concentration in Bay Bolete in that site was low. This can be attributed to 198 low bioavailability of $\mathrm{Hg}$ at this site. Content of methylmercury ( $\mathrm{MeHg}$ ) and its proportion to 199 inorganic $\mathrm{Hg}$ in soils can impact amount of total $\mathrm{Hg}$ sequestered in fruiting bodies (Fischer et al., 200 1995). At the Włoszczowa site $(15 \mathrm{~W})$, relatively elevated $\mathrm{Hg}$ content was found $(0.28$ and 0.17 $\left.201 \mu \mathrm{g} \mathrm{g}^{-1} \mathrm{dw}\right)$ in topsoil, while concentrations in caps $\left(0.081\right.$ and $\left.0.073 \mu \mathrm{g} \mathrm{g}^{-1} \mathrm{dw}\right)$ and in stipes $202\left(0.017\right.$ and $0.040 \mu \mathrm{g} \mathrm{g}^{-1} \mathrm{dw}$ ), were low (BCF between 0.3 and 0.4 for caps and 0.06 and 0.2 for 203 stipes). Thus, the concentrations of $\mathrm{Hg}$ accumulated in fruiting bodies varied widely $(\mathrm{p}<0.05$; 204 Mann-Whitney $U$ test) among the locations surveyed (Table 1).

205 Bioconcentration potential

206 Our results indicate that Bay Bolete can bioconcentrate $\mathrm{Hg}$ from the soil. Mercury was found in 207 Bay Bolete, even in unpolluted areas where the BCF (bioconcentration factor) in caps was up to 
$20811 \pm 6$ (Table 1). Bioconcentration factor or transfer factor (TF) is a quotient of $\mathrm{Hg}$ concentration

209 in caps or stipes to soil $\mathrm{Hg}$ concentration. BCF value below 1 suggests exclusion or bio-exclusion

210 whereas the value above 1 suggests bioconcentration. The values of BCF of $\mathrm{Hg}$ in Bay Bolete

211 decreased with increasing soil $\mathrm{Hg}$ concentration (Figure 4).

$212 \quad H g$ intake rates

213 Both cap and stipe of Bay Bolete are edible and accumulation of $\mathrm{Hg}$ in both parts of this

214 mushroom is a human health concern. In a well-grown fruiting body of this fungus, cap is much

215 larger in mass than stipe, while in young specimens, the proportion is approximately equal, and in 216 much younger specimens, stipe is larger than cap. Nevertheless, there is no published data on $\mathrm{Hg}$ 217 content in caps, stipes or whole fruiting bodies of Bay Bolete collected at different growth stages. 218 The mushroom collectors harvest forest mushrooms daily and individuals, who are late during a 219 mushroom collection day, collect even young fruiting bodies. There are no limits regarding 220 allowable size or allowable daily harvest for mushroom collection or a mushroom species that 221 could be collected by an individual in Poland. For the assessment of daily intake rate of $\mathrm{Hg}$ from 222 Bay Bolete, we assumed that the fruiting bodies were collected from mature specimens.

Although mushrooms do not constitute a significant portion of human diet, they are 224 popular food items worldwide especially during their seasonal abundance. The data regarding 225 intake rates of wild-grown edible mushrooms at local, regional, national, or international scale 226 are highly limited. For example, as discussed by Zhang et al. (2010), consumption rate of wild227 grown mushrooms in Sweden was $1 \mathrm{~kg}$ per capita annually and Common Chanterelle 228 (Cantharellus cibarius) is the most commonly consumed mushroom in that country. In rural 229 areas of Sweden, as well as in rural areas of many other European countries, wild-mushroom 230 picking is a common practice and the intake rates per capita are expected to be greater than $1 \mathrm{~kg}$ 231 annually. In Czech Republic, $72 \%$ of families take part in wild-mushroom picking, with an 
232 average yield of $7 \mathrm{~kg}$ fresh weight per familia annually, while annual intake rate by some 233 individuals can be up to $10 \mathrm{~kg}$ per capita fresh weight. In Sichuan Province in China, the annual 234 wild mushroom consumption rate exceeded 20-24 kg per capita (Zhang et al., 2010).

235 In Poland, a meal of up to $300 \mathrm{~g}$ of fresh mushroom is considered as the common intake 236 rate in a single dish per capita during a week period among mushroom dish fanciers or 237 individuals with low income rural household. A single dish of up to $500 \mathrm{~g}$ of fruiting bodies 238 (fresh weight) collected in wild has been used as daily intake rate of mushrooms per capita. 239 (Zhang et al., 2010).

240 Mushrooms, depending on the species, are cooked in several ways. Any mushroom, wild 241 or cultivated, should not be eaten fresh. Blanching (boiling in water for 10 minutes) of fresh 242 fruiting bodies is a common procedure. Blanched mushrooms could be further baked, used as 243 soup ingredients, pickled, or frozen. Dried mushrooms could be grounded (powdered) and used 244 as a condiment. Dried mushrooms can be soaked in water and added (together with or without 245 broth) to certain traditional dishes and further cooked without loss of mineral constituents. 246 Soaking of fresh fruiting bodies of Bay Bolete in salt ( $2 \%$ of table salt per fresh mushroom 247 weight) water at $20^{\circ} \mathrm{C}$ for 5-15 min resulted in 5-10\% loss of total $\mathrm{Hg}$ content, while boiling for 24815 min resulted in $15 \%$ loss of this element (Svoboda et al., 2001).

249 It is not known if both organic and inorganic forms of $\mathrm{Hg}$ are leached during blanching or 250 other type of processing. A $15 \%$ loss of total $\mathrm{Hg}$ contained in fruiting bodies during blanching of 251 Bay Bolete is considered to be low (Svoboda et al., 2001). Based on the large variation in total $252 \mathrm{Hg}$ content in Bay Bolete (Table 1), the 15\% loss rate from food processing step can be ignored 253 in the assessment of $\mathrm{Hg}$ intake rates by consumers.

254 For the assessment of potential risks from intake of $\mathrm{Hg}$ in the fruiting bodies of Bay 255 Bolete, a reference dose (RfD; $0.0003 \mathrm{mg} \mathrm{kg}^{-1} \mathrm{bm}$ daily) and a Provisional Tolerable Weekly 
256 Intake values (PTWI; $0.005 \mathrm{mg} \mathrm{kg}^{-1} \mathrm{bm}$ ) have been used (JECFA, 1978, US EPA, 1987). The 257 PTWI of $5 \mu \mathrm{g} \mathrm{kg}^{-1}$ body weight for total $\mathrm{Hg}$ established by the JECFA in 1978 was revised in 2582010 (JECFA, 2010). The JECFA established a PTWI of $0.004 \mathrm{mg} \mathrm{kg}^{-1}$ bw for inorganic $\mathrm{Hg}$ in 259 2010, based on the assumption that the predominant form of $\mathrm{Hg}$ in foods, other than fish and 260 shellfish, is inorganic Hg. A meal made with 300-500 g of fresh caps of Bay Bolete collected 261 from the Złotoryja site can result in $\mathrm{Hg}$ intake of $0.00025-0.0004 \mathrm{mg} \mathrm{kg}^{-1}$ bw (assuming a $60 \mathrm{~kg}$ 262 body weight), based on the median $\mathrm{Hg}$ concentration of $0.058 \mu \mathrm{g} \mathrm{g}^{-1}$ wet weight. If the intake is 263 calculated from the arithmetic mean of $0.10 \mu \mathrm{g} \mathrm{Hg} \mathrm{g}^{-1}$ wet weight (assuming $90 \%$ water content 264 in caps), the intake rate will be $0.00043-0.0007 \mathrm{mg} \mathrm{kg}^{-1} \mathrm{bw}$.

265 Wild mushrooms are more frequently and at higher rate eaten in a mushrooming season in 266 late summer and early fall, while usually much less in other periods of the year. In a view of $\mathrm{Hg}$ 267 content, the consumption of Bay Boletes (caps or a whole mushrooms) at the regions surveyed at 268 least at a rate up to $2.5 \mathrm{~kg}$ per capita weekly in a mushrooming season is safe and will not result 269 in exceeding of currently allowable $\mathrm{Hg}$ intake doses.

270 Bay Bolete collected from the Sierakowice site (an unpolluted area) contained the greatest

$271 \mathrm{Hg}$ concentration (Table 1). Consumption of fresh caps of Bay Bolete collected at this site at a 272 rate up to $7.5 \mathrm{~kg}$ should not result in $\mathrm{Hg}$ intake values exceeding the PTWI limit for a person 273 weighing $60 \mathrm{~kg}$, assuming that no $\mathrm{Hg}$ from other foods is ingested. Forest soil at the Złotoryja 274 and Karpacz sites contained elevated concentrations of $\mathrm{Hg}$, and Bay Bolete at the Złotoryja site 275 contained high levels of $\mathrm{Hg}$ (Figure 3; Table 1). Consumption of up to $2.4 \mathrm{~kg}$ of fresh caps of Bay 276 Bolete from Złotoryja should not exceed the PTWI limit, if no $\mathrm{Hg}$ from other foods is ingested.

277 Selenium in mushroom can provide protective role against $\mathrm{Hg}$ (Jarzyńska and Falandysz, 278 2011b). It is presumed that co-occurrence of selenium and $\mathrm{MeHg}$ or total $\mathrm{Hg}$ in stoichiometric 279 ratio could prevent the toxic effects of $\mathrm{Hg}$ in foods (Yoneda and Suzuki, 1997; Stijve and 
280 Cardinale, 1974; Stijve and Besson, 1976). A review of published data on selenium content in a

281 limited number of Bay Bolete samples collected in Europe indicated that selenium content in 282 fruiting bodies usually varies around $0.20 \mu \mathrm{g} \mathrm{g}^{-1} \mathrm{dw}$ (Falandysz, 2008), which is comparable to $283 \mathrm{Hg}$ content found in Bay Bolete in this study (Table 1).

284 The PTWI for MeHg is $0.0016 \mathrm{mg} \mathrm{kg}^{-1}$ bw (JECFA, 2007).We did not analyze MeHg 285 content in Bay Bolete in this study. Fischer et al. (1995) reported that 0.70 to $1.1 \%$ of total $\mathrm{Hg}$ 286 content in Bay Bolete is in the form of $\mathrm{MeHg}$ in a highly contaminated area (15-35 $\mu \mathrm{g} \mathrm{Hg} \mathrm{g}^{-1}$ 287 dw). Pilz et al. (2011) in a recent study reported on $\mathrm{MeHg}$ content of five species of fungi: an 288 unknown fungus, Cordoncella mushroom (King Bolete?), Pleurotus djamer, P. citrinopileatus 289 and P. ostreatus, where this compound varied a somehow between the species but largely varied 290 depending on the extraction method used, i.e. by ultrasonic (from 3 to $38 \%$ of total $\mathrm{Hg}$ ) or 291 microwave assisted extraction (from 15 to $41 \%$ of total $\mathrm{Hg}$ ). Data available on $\mathrm{MeHg}$ in wild 292 mushrooms are sparse and controversial. As reviewed recently, reported $\mathrm{MeHg}$ content of King 293 Bolete (Boletus edulis) varied highly (from 0.6 to $39 \%$ of total $\mathrm{Hg}$ ) between the authors 294 (Falandysz, 2010).

295 Conclusions

$296 \mathrm{Hg}$ concentrations in pooled caps of Bay Bolete collected from unpolluted areas in Poland were 297 below $1.0 \mu \mathrm{g} \mathrm{Hg} \mathrm{g}^{-1} \mathrm{dw}$. Mercury concentrations in caps and stipes of Bay Bolete were strongly 298 correlated $(\mathrm{p}<0.0001)$. The relationship between the concentrations of $\mathrm{Hg}$ in soil and in 299 mushrooms varied depending on the location. The bioconcentration potential of $\mathrm{Hg}$ in Bay Bolete 300 at sites with elevated soil $\mathrm{Hg}$ concentrations was lower than that in soils with low $\mathrm{Hg}$ content. In 301 a view of $\mathrm{Hg}$ content, the consumption of Bay Boletes (caps or a whole mushrooms) at the 302 regions surveyed at least at a rate up to $2.5 \mathrm{~kg}$ per capita weekly in a mushrooming season is safe 303 and will not result in exceeding of currently allowable $\mathrm{Hg}$ intake doses. 
305 Acknowledgement

306 Technical assistance by Joanna Gozdek, Aleksandra Jabłońska, Ewa Łukaszewicz, Dominika Romińska, 307 Daniel Siwicki and Aleksandra Stefańska is acknowledged. This study was supported by the Ministry of 308 Science and Higher Education under the grant no. DS-8130-4-0092-12. This article is a part of a Ph. D. 309 thesis by A.K. Kojta

\section{References}

312 Alonso J, Salgado MJ, Garciá, MÁ, Melgar MJ. 2000. Accumulation of mercury in edible 313 macrofungi: Influence of some factors. Arch. Environ. Contam. Toxicol. 44: 18-162.

314 Barcan V, Kovnatsky EF, Smetannikova MS. 1998. Absorption of heavy metals in wild berries 315 and edible mushrooms in area affected by smelter emissions. Water Air Soil Poll. 103: 173316195.

317 Bargagli R, Baldi F. 1984. Mercury and methyl mercury in higher fungi and their relation with 318 substrata in a cinnabar mining area. Chemosphere. 13: 1059-1071.

319 Borovička J, Kotrba P, Gryndler M, Mihaljevič M, Řanda Z. Rohovec J, Cajthaml T, Stijve T, 320 Dunn CE. 2010. Bioaccumulation of silver in ectomycorrhizal and saprobic macrofungi from 321 pristine and polluted areas. Sci. Total Environ. 408: 2733-2744.

323 Brzostowski A, Bielawski L, Orlikowska A, Plichta S, Falandysz J. 2009. Instrumental analysis 324 of metals profile in Poison Pax (Paxillus involutus) collected at two sites in Bory Tucholskie. 325 Chem. Anal. (Warsaw). 54: 907-919. 
326 Brzostowski A, Jarzyńska G, Falandysz J, Zhang D. 2011a. Bioconcentration potential of 327 metallic elements by Poison Pax (Paxillus involutus) mushroom. J. Environ. Sci. Health Part $328 \quad$ A. $46: 378-393$.

329 Brzostowski A, Jarzyńska G, Kojta AK, Wydmańska D, Falandysz J. 2011b. Variations in metal 330 levels accumulated in Poison Pax (Paxillus involutus) mushroom collected at one site over four 331 years. J. Environ. Sci. Health Part A. 46: 581-588.

332 Carvalho MI, Pimentel AC. Fernandes B. 2005. Study of heavy metals in wild edible mushrooms 333 under different pollution conditions by X-ray fluorescence spectrometry. Anal. Sci. 21: 747334750.

335 Chudzyński K, Bielawski L, Falandysz J. 2009. Mercury bio-concentration potential of Larch 336 Bolete, Suillus grevillei, mushroom. Bull. Environ. Contam. Toxicol. 83: 275-279.

337 Chudzyński K, Falandysz J. 2008. Multivariate analysis of elements content of Larch Bolete 338 (Suillus grevillei) mushroom. Chemosphere. 73: 1230-1239.

339 Chudzyński K, Jarzyńska G, Stefańska A, Falandysz J. 2011. Mercury content and bio340 concentration potential of Slippery Jack, Suillus luteus, mushroom. Food Chem. 125: 986-990.

341 Cibulka J, Šišák L, Pulkrab K, Miholová D, Száková J, Fučiková A, Slámova A, Stéhulová J, 342 Barláková S. 1996. Cadmium, lead, mercury and caesium levels in wild mushrooms and forest 343 berries from different localities of Czech Republic. Sci. Agaricult. Bohem. 27: 113-129.

344 Doğan HH, Sanda MA Uyanőz R, Oztürk C, Çetin Ü. 2006. Contents of metals in some wild 345 mushrooms: its impact in human health. Biol. Trace Elem. Res. 110: 79-94.

346 Falandysz J. 2002. Mercury in mushrooms and soil of the Tarnobrzeska Plain, south-eastern 347 Poland. J. Environ. Sci. Health Part A. 37: 343-352.

348 Falandysz J. 2008. Selenium in edible mushrooms. J. Environ. Sci. Health Part C. 26: 256-299. 
349 Falandysz J. 2010. Progress in Mycology. Jodhpur: Scientific Publishers. Mercury in certain 350 mushrooms species in Poland; p. 349-383.

351 Falandysz J, Bielawski L. 2001. Mercury content of wild edible mushrooms collected near the 352 town of Augustow. Pol. J. Environ. Stud. 10: 67-71.

353 Falandysz J, Bielawski L. 2007. Mercury and its bioconcentration factors in Brown Birch Scaber 354 Stalk (Leccinum scabrum) from various sites in Poland. Food Chem. 105: 635-640.

355 Falandysz J, Bielawski L, Kannan K, Gucia M, Lipka K, Brzostowski A. 2002a. Mercury in wild 356 mushrooms and underlying soil substrate from the great lakes land in Poland. J. Environ. 357 Monit. 4: 473-476.

358 Falandysz J, Bona H, Danisiewicz D. 1994. Silver uptake by Agaricus bisporus from an 359 artificially enriched substrate. Zeitschr. Lebensm. Unters. Forsch. 199: 225-228.

360 Falandysz J, Brzostowski A. 2007. Mercury and its bioconcentration factors in Poison Pax 361 (Paxillus involutus) from various sites in Poland. J. Environ. Sci. Health Part A. 42: 10953621100.

363 Falandysz J, Brzostowski A, Kawano M, Kannan K, Puzyn T, Lipka K. 2003a. Concentrations of 364 mercury in wild growing higher fungi and underlying substrate near Lake Wdzydze, Poland. 365 Water Air Soil Pollut. 148: 127-137.

366 Falandysz J, Chwir A. 1997. The concentrations and bioconcentration factors of mercury in 367 mushrooms from Mierzeja Wislana sand-bar, Northern Poland. Sci. Total Environ. 203: 221368228.

369 Falandysz J, Frankowska A, Jarzyńska G, Dryżałowska A, Kojta AK, Zhang D. 2011. Survey on 370 composition and bioconcentration potential of 12 metallic elements in King Bolete (Boletus 371 edulis) mushroom that emerged at 11 spatially distant sites. J. Environ. Sci. Health Part B. 46: $372 \quad 231-246$. 
373 Falandysz J, Frankowska A, Mazur A. 2007a. Mercury and its bioconcentration factors in King 374 Bolete (Boletus edulis). J. Environ. Sci. Health Part A. 42: 2089-2095.

375 Falandysz J, Gucia M. 2008. Bioconcentration factors of mercury by parasol mushroom 376 (Macrolepiota procera). Environ. Geochem. Health. 30: 121-125.

377 Falandysz J, Gucia M, Brzostowski A, Kawano M, Bielawski L, Frankowska A, Wyrzykowska 378 B. 2003b. Content and bioconcentration of mercury in mushrooms from northern Poland. Food 379 Addit. Contam., 20: 247-253.

380 Falandysz J, Gucia M, Frankowska A, Kawano M, Skwarzec B. 2001a. Total mercury in wild 381 mushrooms and underlying soil substrate from the city of Umeå and its surroundings, Sweden. 382 Bull. Environ. Contam. Toxicol. 67: 767-770.

383 Falandysz J, Gucia M, Mazur A. 2007b. Content and bioconcentration factors of mercury by 384 Parasol Mushroom Macrolepiota procera. J. Environ. Sci. Health Part B. 42: 735-740.

385 Falandysz J, Gucia M, Skwarzec B, Frankowska A, Klawikowska K (2002b) Total mercury in 386 mushrooms and underlying soil from the Borecka Forest, Northeastern Poland. Arch. Environ. 387 Contam. Toxicol. 42: 145-154.

388 Falandysz J, Jędrusiak A, Lipka K, Kannan K, Kawano M, Gucia M, Brzostowski A, Dadej M. 389 2004. Mercury in wild mushrooms and underlying soil substrate from Koszalin, North-central $390 \quad$ Poland. Chemosphere. 54: 461-466.

391 Falandysz J, Kawano M, Świeczkowski A, Brzostowski A, Dadej M. 2003c. Total mercury in 392 wild-grown higher mushrooms and underlying soil from Wdzydze Landscape Park, Northern 393 Poland. Food Chem. 81: 21-26.

394 Falandysz J, Kunito T, Kubota R, Bielawski L, Frankowska A, Falandysz JJ, Tanabe S. 2008 a. 395 Multivariate characterization of elements accumulated in King Bolete Boletus edulis 
396 mushroom at lowland and high mountain regions. J. Environ. Sci. Health Part A. 43: 1692$397 \quad 1699$.

398 Falandysz J, Kunito T, Kubota R, Brzostowski A, Mazur A, Falandysz JJ, Tanabe S. 2007c. 399 Selected elements of Poison Pax Paxillus involutus. J. Environ. Sci. Health Part A. 42: 1161$400 \quad 1169$.

401 Falandysz J, Kunito T, Kubota R, Gucia M, Mazur A, Falandysz JJ, Tanabe S. 2008b. Some 402 mineral constituents of Parasol Mushroom Macrolepiota procera. J. Environ. Sci. Health Part $403 \quad$ B. $43: 187-192$.

404 Falandysz J, Kunito T, Kubota R, Lipka, K.; Mazur, A.; Falandysz, J.J.; Tanabe, S. 2007d. 405 Selected elements in Fly Agaric Amanita muscaria. J. Environ. Sci. Health Part A. 42: 16154061623.

407 Falandysz J, Lipka K, Gucia M, Kawano M, Strumnik K, Kannan K. 2002c. Accumulation 408 factors of mercury in mushrooms from Zaborski Landscape Park, Poland. Environ. Intern. 28: $409 \quad 421-427$.

410 Falandysz J, Lipka K, Kawano M, Brzostowski A, Dadej M, Jędrusiak A, Puzyn T. 2003 d. 411 Mercury content and its bioconcentration factors in wild mushrooms at Łukta and Morag, $412 \quad$ Northeastern Poland. J. Agric. Food Chem. 51: 2832-2836.

413 Falandysz, J.; Lipka, K.; Mazur, A. 2007e. Mercury and its bioconcentration factors in Fly Agaric 414 (Amanita muscaria) from spatially distant sites in Poland. J. Environ. Sci. Health Part A. 42: $415 \quad 1625-1630$.

416 Falandysz J, Szymczyk K, Ichihashi H, Bielawski L, Gucia M, Frankowska A, Yamasaki S. 417 2001b. ICP/MS and ICP/AES elemental analysis (38 elements) of edible wild mushrooms 418 growing in Poland. Food Addit. Contam. 18: 503-513. 
419 Fischer RG, Rapsomanikis S, Andreae MO, Baldini F. 1995. Bioaccumulation of methylmercury 420 and transformation of inorganic mercury by macrofungi. Environ. Sci. Technol. 29: 993-999.

421 Frankowska A, Ziółkowska J, Bielawski L, Falandysz J. 2010. Profile and bioconcentration of 422 minerals by King Bolete (Boletes edulis) from the Płocka Dale in Poland. Food Add. Contam. 423 Part B. 3: 1-6.

424 Gast CH, Jansen E, Bierling J, Haanstra L. 1988. Heavy metals in mushrooms and their 425 relationship with soil characteristics. Chemosphere. 17: 789-799.

426 Gucia M, Jarzyńska G, Kojta AK, Falandysz J. 2012a. Temporal variability in mineral substances 427 of Parasol Mushroom (Macrolepiota procera) collected in the same sites. J. Environ. Sci. $428 \quad$ Health Part B. 47: in press.

429 Gucia M, Kojta AK, Jarzyńska G, Rafał E, Roszak M, Osiej I, Falandysz J. 2012b. Multivariate 430 analysis of mineral constituents of edible Parasol Mushroom (Macrolepiota procera) and soils 431 beneath fruiting bodies collected from Northern Poland. Environ. Sci. Pollut. Res. 18: doi. $432 \quad 10.1007 / \mathrm{s} 11356-011-0574-5$.

433 GUS: Informator i opracowania statystyczne, Leśnictwo 2009 [Internet]. 2009. Warszawa: 434 Główny Urząd Statystyczny, ISSN 1230-574x; [cited 2010]. Available from: $435 \quad$ http://www.stat.gov.pl.

436 Jarzyńska G, Falandysz J. 2011a. The determination of mercury in mushrooms by CV-AAS and 437 ICP-AES techniques. J. Environ. Sci. Health Part A. 46: 569-573.

438 Jarzyńska G, Falandysz J. 2011b. Selenium and 17 other largely essential and toxic metals in 439 muscle and organ meats of Red Deer (Cervus elaphus) - Consequences to human health. $440 \quad$ Environ. Intern. 37: 882-888. 
441 Jarzyńska G, Gucia M, Kojta AK, Rezulak K, Falandysz J. 2011. Profile of trace elements in 442 Parasol Mushroom (Macrolepiota procera) from Tucholskie Forest. J. Environ. Sci. Health 443 Part B. 46: 741-751.

444 JECFA. 1978. Evaluation of certain food additives and contaminants. Twenty-second report of 445 the Joint FAO/WHO Expert Committee on Food Additives, WHO Technical Report Series $446 \quad 631$.

447 JECFA. 2007. Evaluation of certain food additives and contaminants. Sixty-seventh report of the 448 Joint FAO/WHO Expert Committee on Food Additives, WHO Technical Report Series 940.

449 JECFA. 2010. Joint FAO/WHO Expert Committee on Food Additives. Seventy-second meeting. 450 Rome, 16-25 February 2010. Summary and Conclusions. JECFA/72/SC. Food and Agriculture 451 Organization of the United Nations and World Health Organization. 16th March 2010.

452 Kojta AK, Gucia M, Jarzyńska G, Lewandowska M, Zakrzewska A, Falandysz J, Zhang D.: 453 2011. Phosphorous and metallic elements in Parasol Mushroom (Macrolepiota procera) and 454 soil from the Augustowska Forest and Ełk regions in north-eastern Poland. Fresen. Environ. 455 Bull. 20: 3044-3052.

456 Malinowska E, Szefer P, Falandysz J. 2004. Metals bioaccumulation by bay bolete, Xerocomus 457 badius, from selected sites in Poland. Food Chem. 84: 405-416.

458 Melgar MJ, Alonso J, Garciá MÁ. 2009. Mercury in edible mushrooms and soil. 459 Bioconcentration factors and toxicological risk. Sci. Total Environ. 407: 5328-5334.

460 Melgar MJ, Alonso J, Pérez-López M, Garcia MÁ. 1998. Influence of some factors in toxicity 461 and accumulation of cadmium from edible wild macrofungi in NW Spain. J. Environ. Sci. $462 \quad$ Health Part B. 33: 439-455.

463 Olivero J, Johnson B, Arguello E, 2002. Human exposure to mercury in San Jorge river basin, 464 Colombia (South America). Sci. Total Environ. 289: 41-47. 
465 Pilz C, Santos CMM, Nunes NAC, Müller EI, Flores ÉMM, Dressler V1. 2011. Speciation of Hg

466 in edible mushroom. Paper presented at: International Symposium Trace Elements in Food.

467 TEF-4; 19-22 June 2011; King’s College, Aberdeen, Scotland..

468 Rundgren S, Rühling Å, Schluter K, Tyler G. 1992. Mercury in Soil - distribution, speciation and 469 biological effects. A review of the literature and comments on critical concentrations. Nordic $470 \quad$ Council of Ministers, Copenhagen.

471 Řanda Z, Kučera J. 2004. Trace elements in higher fungi (mushrooms) determined by activation 472 analysis. J. Radioanal. Nuclear Chem. 259: 99-107.

473 Stijve T, Besson R. 1976. Mercury, cadmium, lead and selenium content of mushroom species 474 belonging to the genus Agaricus. Chemosphere. 7: 151-158.

475 Stijve T, Cardinale E. 1974. Selenium and mercury content of some edible mushrooms. Trav. $476 \quad$ chim. alim. d'hyg. 65: 476-478.

477 Stijve T, Goessler W, Dupuy G. 2004. Influence of soil particles on concentrations of aluminium, 478 iron, calcium and other metals in mushrooms. Deutsch. Lebensm-Rundsch. 100: 10-13.

479 Stijve T, Roschnik R. 1974. Mercury and methyl mercury content of different species of fungi. $480 \quad$ Trav. chim. alim. d'hyg. 65: 209-220.

481 Suchara I, Sucharová J. 2002. Distribution of sulphur and heavy metals in forest floor humus of 482 the Czech Republic. Water Air Soil Pollut. 136: 289-316.

483 Svoboda L, Kalač P, Špička J, Janoušková D. 2001. Leaching of cadmium, lead and mercury 484 from fresh and differently preserved edible mushrooms, Xerocomus badius, during soaking and 485 boiling. Food Chem. 79: 41-45.

486 Tipping E, Lofts S, Hooper H, Frey B, Spurgeon D, Svendsen C. 2010. Critical Limits for Hg(II) 487 in soils, derived from chronic toxicity data. Environ. Pollut. 158: 2465-2471. 
488 US EPA. 1987. United States Environmental Protection Agency Peer Review Workshop on 489 Mercury Issues. Summary Report. Environmental Criteria and Assessment Office. Cincinnati, 490 OH: U.S. EPA. October 26-27.

491 Yoneda S, Suzuki KT. 1997. Detoxification of mercury by selenium by binding of equimolar Hg492 Se complex to a specific plasma protein. Toxicol. Appl. Pharmacol. 143: 274-280.

493 Zhang D, Frankowska A, Jarzyńska G, Kojta AK, Drewnowska M, Wydmańska D, Bielawski L, 494 Wang J, Falandysz J. 2010. Metals of King Bolete (Boletus edulis) collected at the same site 495 over two years. Afr. J. Agric. Res. 5: 3050-3055.

496 Zimmermannova K, Svoboda L, Kalač P. 2001. Mercury, cadmium, lead and copper contents in 497 fruiting bodies of selected edible mushrooms in contaminated Middle Spiš region Ekologia 498 (Bratislava). 20: 440-446.

$500 \quad$ Figure Captions

501 Figure 1. Locations of the sampling sites of Bay Bolete in Poland. Abbreviations: The communes 502 of Sierakowice (1) and Lipusz in Pomorskie Voivodeship (2); Augustowska Forest in Podlaskie 503 Voivodeship (3); Olsztynek (4) Szczytno in Warmia and Mazury Voivodeship (5); Commune of 504 Olszewo-Borki in Mazowieckie Voivodeship (6); Notecka Forest (7), Porażyn (8), Rogalin (9) 505 Turek in Wielkopolska Voivodeship (10); Lower Silesia Forest (11), Złotoryja (12), Karpacz (13) 506 and Kłodzka Dale in Dolnośląskie Voivodeship (14); Włoszczowa (15) and Starachowickie 507 Forest in Świętokrzyskie Voivodeship (16); Poniatowa in Lubelskie Voivodeship (17);

508 Chochołowska Valley in Małopolska Voivodeship (18). 509

510 Figure 2. Plot of $\mathrm{Hg}$ concentrations in caps against its concentrations in stipes of 221 fruit bodies 511 of Bay Bolete collected from Poland $\left(\mathrm{y}=0.0231+1.4949 * \mathrm{x} ; \mathrm{r}=0.95 ; \mathrm{r}^{2}=0.89 ; \mathrm{p}<0.0001\right)$. 
513 Figure 3. Median values of $\mathrm{Hg}$ concentration in caps or in whole specimens of Bay Bolete and in

514 soil substrate collected under mushrooms: the sampling sites are displayed starting from the north

515 to the south of Poland. Abbreviations: CS (1) Mojusz in Commune of Sierakowice and CL (2)

516 Commune of Lipusz in Pomorskie Voivodeship; AF (3) Augustowska Forest in Podlaskie

517 Voivodeship; O (4) Olsztynek and S (5) Szczytno in Warmia and Mazury Voivodeship; O-B (6)

518 Commune of Olszewo-Borki in Mazowieckie Voivodeship; NF (7) Notecka Forest, P (8)

519 Porażyn, R (9) Rogalin and T (10) Turek in Wielkopolska Voivodeship; LSF (11) Lower Silesia

520 Forest, Z (12) Złotoryja, K (13) Karpacz and KD (14) Kłodzka Dale in Dolnośląskie

521 Voivodeship; W (15) Włoszczowa and SF (16) Lipie in Starachowickie Forest in Świętokrzyskie

522 Voivodeship; P-LV (17) Poniatowa in Lubelskie Voivodeship; CH (18) Chochołowska Valley in 523 Małopolska Voivodeship. 
1 Table 1. Mean, standard deviation, range and median values of total mercury concentration in fruiting bodies of mushroom and soil,

2 and cap to stipe concentration quotient and bioconcentration factor (BCF) values for mercury.

\begin{tabular}{|c|c|c|c|c|c|c|}
\hline \multirow{2}{*}{$\begin{array}{l}\text { Site, year and number } \\
\text { of samples }\end{array}$} & \multicolumn{3}{|c|}{$\mathrm{Hg}(\mu \mathrm{gg}-1 \mathrm{dw})$} & \multirow[b]{2}{*}{$\mathrm{Q}_{\mathrm{C} / \mathrm{S}}$} & \multicolumn{2}{|c|}{$\mathrm{BCF}$} \\
\hline & Cap & Stipe & Soil & & Cap & Stipe \\
\hline 1 (CS) Mojusz, Commune & $0.32 \pm 0.17$ & $0.23 \pm 0.12$ & $0.11 \pm 0.09$ & $1.4 \pm 0.3$ & $5.4 \pm 5.4$ & $4.1 \pm 4.1$ \\
\hline of Sierakowice, Pomorskie & $(0.13-0.65)$ & $(0.081-0.43)$ & $(0.024-0.26)$ & $(0.95-2.1)$ & $(0.86-17)$ & $(0.42-13)$ \\
\hline 2 (CL) Commune Lipusz, & $0.14 \pm 0.09$ & $0.070 \pm 0.02$ & $0.046 \pm 0.033$ & $2.0 \pm 1.3$ & $3.9 \pm 2.5$ & $2.0 \pm 1.3$ \\
\hline Pomorskie Voivodeship, & $(0.080-0.41)$ & $(0.039-0.13)$ & $(0.022-0.14)$ & $(1.3-6.6)$ & $(0.60-8.4)$ & $(0.45-5.1)$ \\
\hline $2006 n=15$ & 0.10 & 0.063 & 0.037 & 1.6 & 3.1 & 1.6 \\
\hline$n=15$ & 0.091 & 0.060 & 0.046 & 1.5 & 1.5 & 1.2 \\
\hline $4(\mathrm{O})$ Olsztynek, Warmia and & $0.080 \pm 0.020$ & $0.044 \pm 0.013$ & $0.051 \pm 0.043$ & $1.9 \pm 0.4$ & $2.2 \pm 1.3$ & $1.2 \pm 0.7$ \\
\hline Mazury Voivodeship, 2002 & $(0.052-0.13)$ & $(0.031-0.083)$ & $(0.013-0.20)$ & $(1.1-2.5)$ & $(0.29-5.1)$ & $(0.21-2.9)$ \\
\hline$n=15$ & 0.077 & 0.040 & 0.041 & 1.9 & 2.1 & 1.1 \\
\hline 5 (S) Szczytno, Warmia & $0.061 \pm 0.013$ & $0.040 \pm 0.009$ & $0.040 \pm 0.010$ & $1.6 \pm 0.2$ & $1.6 \pm 0.6$ & $1.1 \pm 0.4$ \\
\hline $\begin{array}{l}\text { Mazowieckie Voivodeship, } \\
2007 n=15\end{array}$ & 0.18 & 0.12 & 0.022 & 1.6 & 13 & 4.4 \\
\hline 7(NF) Notecka Forest, & $0.057 \pm 0.028$ & $0.048 \pm 0.023$ & $0.038 \pm 0.027$ & $1.5 \pm 1.0$ & $2.0 \pm 1.3$ & $1.9 \pm 1.5$ \\
\hline Wielkopolska Voivodeship, & $(0.028-0.13)$ & $(0.007-0.091)$ & $(0.009-0.072)$ & $(0.68-4.4)$ & $(0.46-5.2)$ & $(0.18-5.5)$ \\
\hline $2008 n=15$ & 0.055 & 0.043 & 0.028 & 0.98 & 1.7 & 1.9 \\
\hline $8(\mathrm{P})$ Porażyn, & $0.052 \pm 0.025$ & $0.031 \pm 0.017$ & $0.073 \pm 0.030$ & $1.7 \pm 0.5$ & $1.1 \pm 1.3$ & $0.64 \pm 0.71$ \\
\hline Wielkopolska Voivodeship, & $(0.011-0.092)$ & $(0.009-0.073)$ & $(0.010-0.12)$ & $(0.31-2.8)$ & $(0.16-5.4)$ & $(0.074-3.0)$ \\
\hline $2008(15)$ & 0.057 & 0.032 & 0.077 & 1.8 & 0.78 & 0.45 \\
\hline 9 (R) Rogalin, Wielkopolska & $0.092 \pm 0.050$ & $0.042 \pm 0.021$ & $0.10 \pm 0.08$ & $2.2 \pm 0.7$ & $2.3 \pm 2.8$ & $1.0 \pm 1.3$ \\
\hline Voivodeship, & $(0.019-0.19)$ & $(0.013-0.088)$ & $(0.010-0.27)$ & $(0.67-3.2)$ & $(0.12-8.8)$ & $(0.091-4.1)$ \\
\hline
\end{tabular}




\begin{tabular}{|c|c|c|c|c|c|c|}
\hline $2008 n=14$ & 0.088 & 0.041 & 0.098 & 2.3 & 1.2 & 0.50 \\
\hline 10 (T) Turek, Wielkopolska & $0.051 \pm 0.030$ & $0.027 \pm 0.018$ & $0.048 \pm 0.006$ & $2.3 \pm 1.4$ & $1.1 \pm 0.6$ & $0.58 \pm 0.38$ \\
\hline $2001-2002 n=11$ & 0.041 & 0.027 & 0.046 & 1.7 & 0.76 & 0.47 \\
\hline Forest, Dolnośląskie & $(0.071-0.78)$ & $(0.026-0.37)$ & $(0.044-0.41)$ & $(1.3-4.2)$ & $(0.44-5.0)$ & $(0.22-2.3)$ \\
\hline $\begin{array}{l}\text { Voivodeship, } \\
2008 n=11\end{array}$ & 0.13 & 0.079 & 0.12 & 2.0 & 1.0 & 0.49 \\
\hline $2008 n=9$ & 0.58 & 0.30 & 0.36 & 1.0 & 1.5 & 1.0 \\
\hline $13(\mathrm{~K})$ Karpacz, & $0.25 \pm 0.14$ & $0.13 \pm 0.06$ & $0.50 \pm 0.20$ & $2.1 \pm 0.9$ & $0.55 \pm 0.31$ & $0.28 \pm 0.13$ \\
\hline Dolnośląskie Voivodeship, & $(0.087-0.53)$ & $(0.059-0.24)$ & $(0.16-0.77)$ & $(0.39-4.5)$ & $(0.19-1.2)$ & $(0.12-0.49)$ \\
\hline $2008 n=15$ & 0.19 & 0.092 & 0.46 & 2.0 & 0.49 & 0.28 \\
\hline $\begin{array}{l}14 \text { (KD) Kłodzka Dale, } \\
\text { Sudety Mountains, }\end{array}$ & \multicolumn{2}{|c|}{$\begin{array}{c}0.26 \pm 0.06 \\
(0.18-0.32)\end{array}$} & $\begin{array}{c}0.15 \pm 0.01^{* * *} \\
(0.13-0.17)\end{array}$ & & \multicolumn{2}{|c|}{$\begin{array}{l}1.3 \pm 0.5 \\
(1.3-2.4)\end{array}$} \\
\hline $2007 \mathrm{n}=15$ & 0.098 & 0.042 & 0.047 & 2.5 & 2.3 & 1.1 \\
\hline 16 (SF) Lipie, & $0.11 \pm 0.03$ & $0.084 \pm 0.040$ & $0.14 \pm 0.05$ & $1.5 \pm 0.4$ & $0.87 \pm 0.39$ & $0.68 \pm 0.49$ \\
\hline Starachowickie Forest, & $(0.073-0.20)$ & $(0.038-0.17)$ & $(0.074-0.21)$ & $(0.55-2.1)$ & $(0.34-1.7)$ & $(0.18-2.2)$ \\
\hline $\begin{array}{l}\text { Świętokrzyskie Voivodeship, } \\
2000 \mathrm{n}=15\end{array}$ & 0.11 & 0.075 & 0.15 & 1.6 & 0.75 & 0.51 \\
\hline 17 (P-LV) Poniatowa, & $0.16 \pm 0.04$ & $0.082 \pm 0.028$ & & $2.0 \pm 0.5$ & & \\
\hline Lubelskie Voivodeship, & $(0.12-0.2)$ & $(0.062-0.13)$ & & $(1.7-2.1)$ & & \\
\hline $2008 n=15$ & 0.14 & 0.070 & ND & 1.7 & ND & ND \\
\hline 18 (CH) Chochołowska Dale, & $0.24 \pm 0.10$ & $0.15 \pm 0.01$ & & $1.5 \pm 0.4$ & & \\
\hline Małopolska Voivodeship, & $(0.10-0.42)$ & $(0.13-0.17)$ & & $(0.84-2.4)$ & & \\
\hline Tatra Mountains, $2000 n=9$ & 0.24 & 0.14 & ND & 1.5 & ND & ND \\
\hline
\end{tabular}

3 Notes: *Number of samples and number of specimens (in parentheses); ND, not determined; ${ }^{* *}$ a whole fruiting bodies; ${ }^{* * *} 15$ samples 


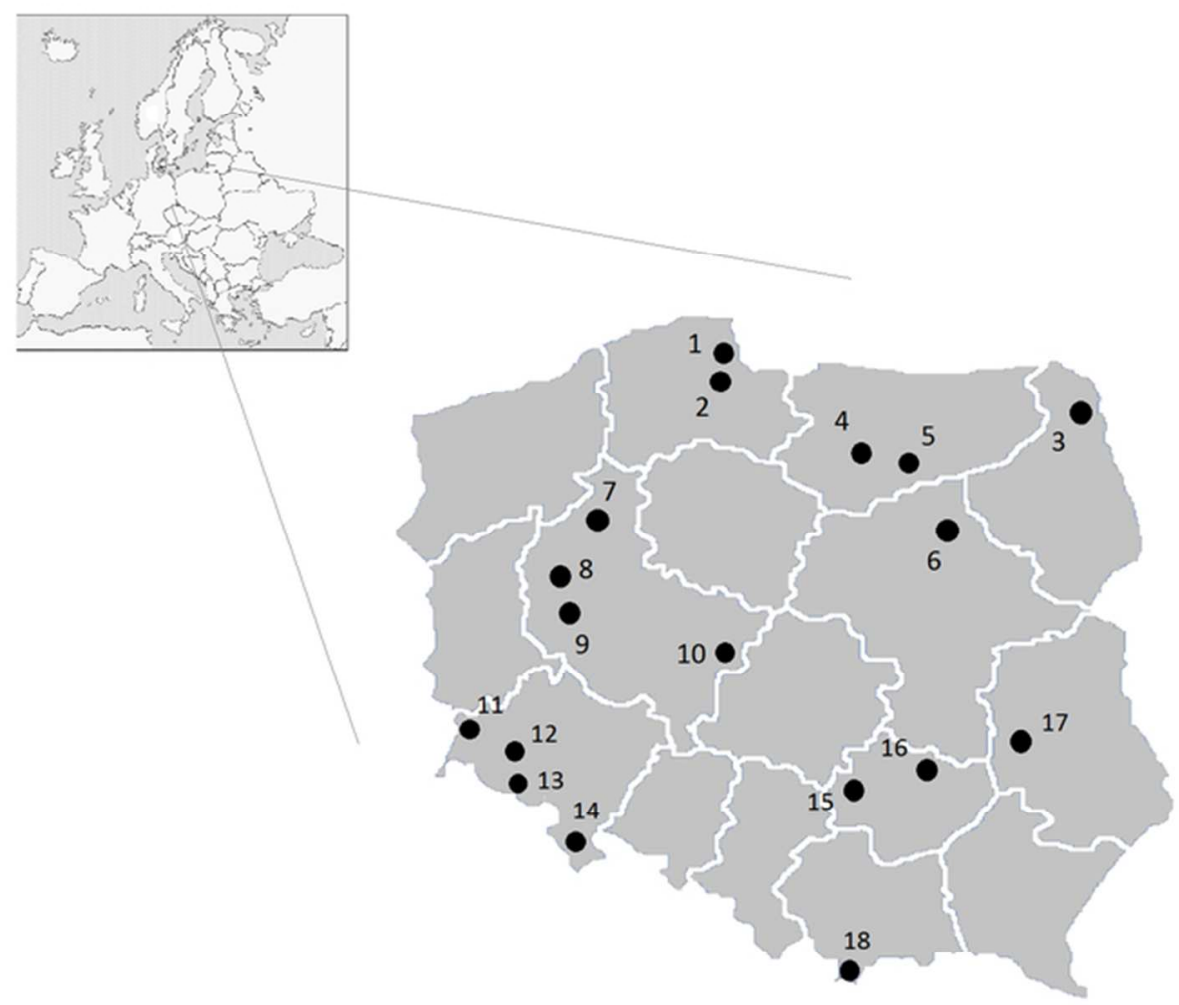

$30 \times 26 \mathrm{~mm}(600 \times 600 \mathrm{DPI})$ 


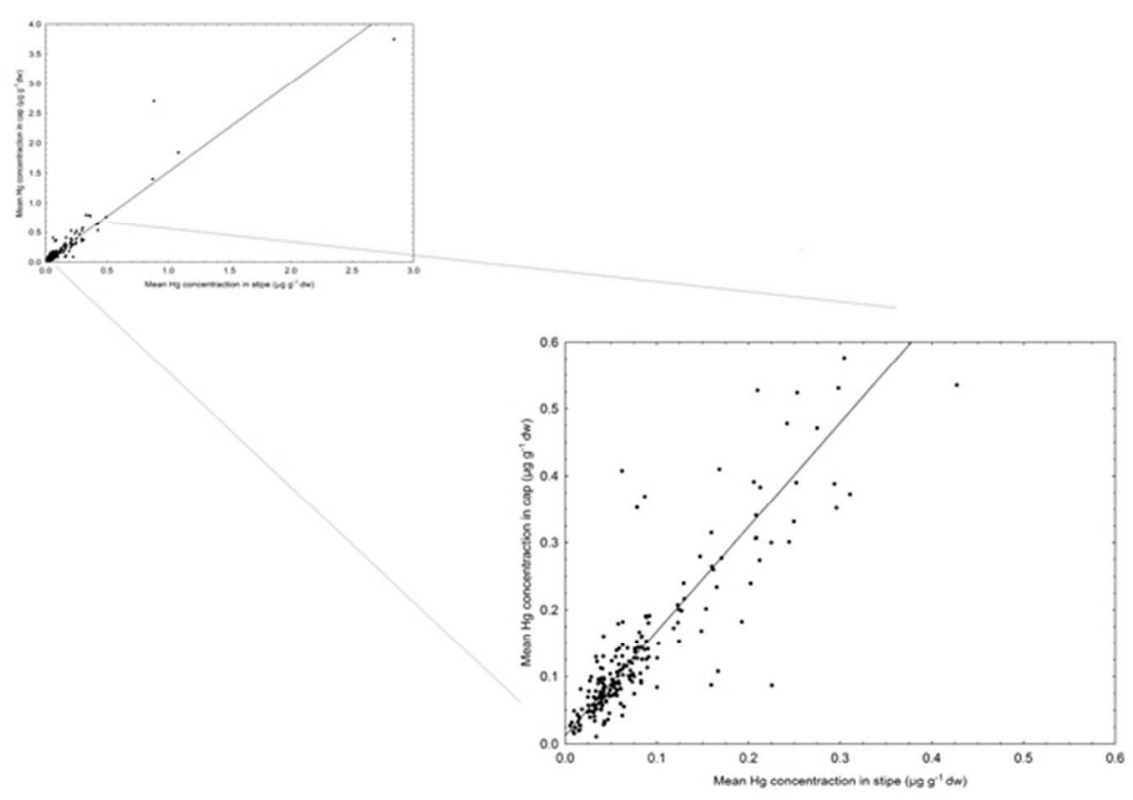

$30 \times 22 \mathrm{~mm}(600 \times 600 \mathrm{DPI})$ 


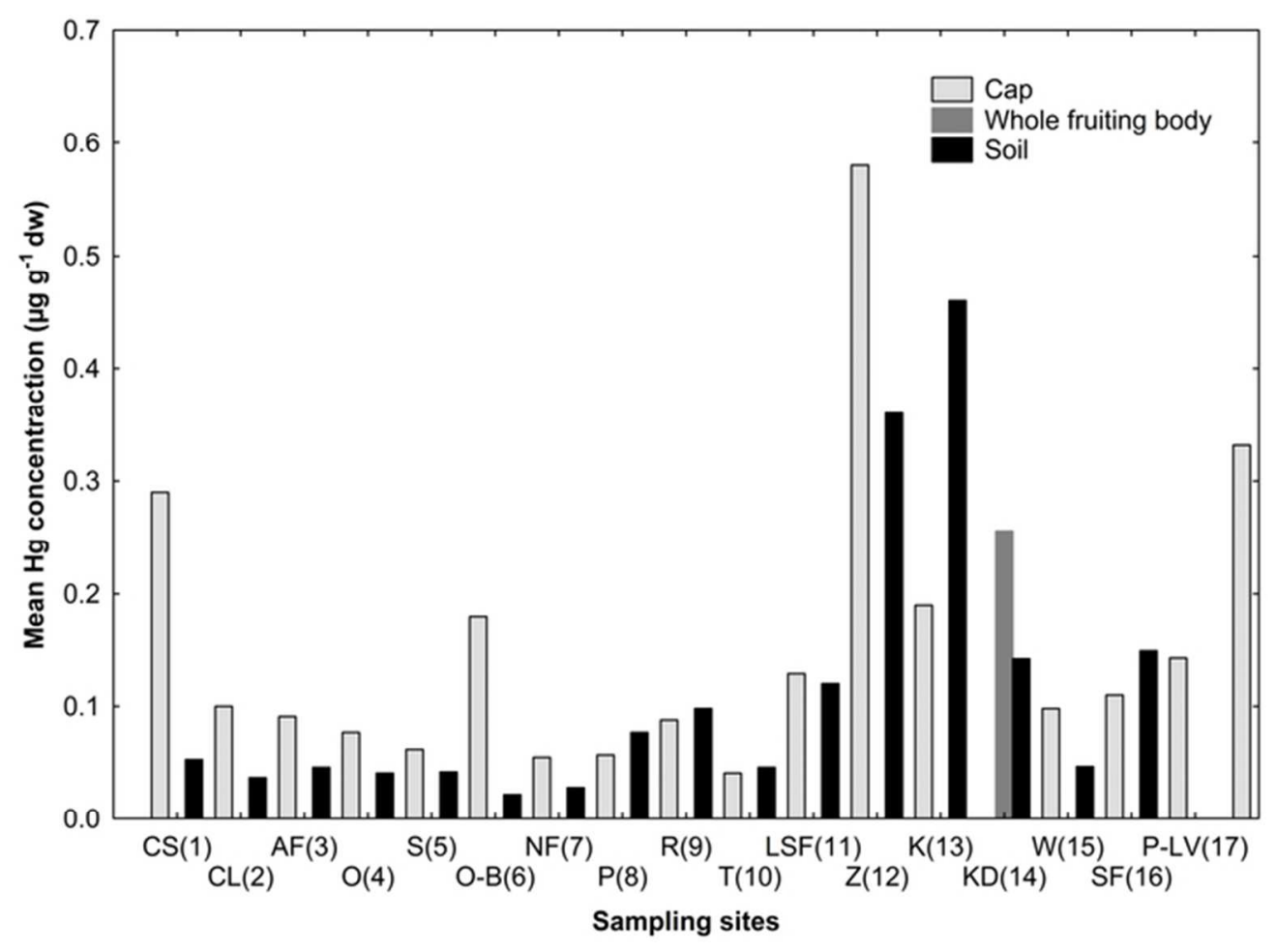

$30 \times 22 \mathrm{~mm}(600 \times 600 \mathrm{DPI})$ 